\title{
A Bibliometric Analysis of Food-Energy-Water Nexus Literature
}

\author{
Adenike K. Opejin ${ }^{1, *}$, Rimjhim M. Aggarwal ${ }^{1}$, Dave D. White ${ }^{2}{ }^{\circledR}$, J. Leah Jones ${ }^{1}{ }^{\circledR}$, \\ Ross Maciejewski ${ }^{3}$, Giuseppe Mascaro ${ }^{4}$ and Hessam S. Sarjoughian ${ }^{3}$ \\ 1 School of Sustainability, Arizona State University, Tempe, AZ 85281, USA; \\ Rimjhim.Aggarwal@asu.edu (R.M.A.); jljone48@asu.edu (J.L.J.) \\ 2 School of Community Resources and Development, Arizona State University, Phoenix, AZ 85004, USA; \\ Dave.White@asu.edu \\ 3 School of Computing, Informatics \& Decision Systems Engineering, Arizona State University, \\ Tempe, AZ 85281, USA; rmacieje@asu.edu (R.M.); Hessam.Sarjoughian@asu.edu (H.S.S.) \\ 4 School of Sustainable Engineering and the Built Environment, Arizona State University, \\ Tempe, AZ 85281, USA; Giuseppe.Mascaro@asu.edu \\ * Correspondence: adenike.opejin@asu.edu; Tel.: +1-480-845-9165
}

Received: 16 December 2019; Accepted: 2 February 2020; Published: 4 February 2020

check for updates

\begin{abstract}
Rapid growth in the food-energy-water (FEW) nexus literature calls for an assessment of the trajectory and impacts of this scholarship to identify key themes and future research directions. In this paper, we report on a bibliometric analysis of this literature that focuses on (1) examining publication trends and geographic focus of research, (2) identifying research hotspots and emerging themes, (3) assessing the integrated nature of research, and (4) reflecting on major developments and ways forward. We used Elsevier's SCOPUS database to search for publications from January 2011 to May 2018 on the FEW nexus, and analyzed the final sample of 257 publications using BibExcel and Vosviewer software tools. The analysis showed steady growth in publications since 2011 with a sharp upturn in 2015 and 2016, coinciding with major funding calls. Thematic analysis of abstracts revealed a strong focus on quantitative resource interlinkages with limited attention to qualitative institutional capacities and intersectoral governance challenges. Term co-occurrence network map showed the term "investment" connected with a large number of frequently cited terms, while the term "governance" demonstrated much weaker links. We reflect on how these findings may help us better understand and address the enduring challenge of transitioning from nexus thinking to action.
\end{abstract}

Keywords: bibliometrics; food-energy-water nexus; publications characteristics; thematic analysis

\section{Introduction}

Population growth, urbanization, and rising demand are increasing pressure on land, water, and energy resources globally [1,2]. Furthermore, the regional effects of global climate change are projected to exacerbate resource scarcity [3]. Public, private, and nonprofit actors have identified food, energy, and water resource scarcity as critical global priorities because of the importance of these resources for human societies and livelihoods [4]. Traditionally, these resources have been governed and managed separately, with the principal authority given to sector-specific agencies tasked with decision making about a specific resource $[5,6]$. The agencies do not usually account for the interaction between these resources. Hence, decisions in one sector can trigger rippling effects that might increase risks in the other sectors. This has led to the emergence of the food-energy-water (FEW) nexus as an approach explicitly focused on examining cross-sectoral interactions [7-11] to address complex resource challenges and help formulate cross-sectoral policies [12]. 
As many scholars have noted, the idea of an underlying nexus between natural resource sectors is not new [1,13]. Scott et al. [14] traced the origins of the nexus idea to the spread of energy and water-intensive technologies associated with the green revolution in South Asia and the Middle East, which raised scholarly interest in energy-water nexus issues in the context of food production. Two sector linkages, such as water-food, food-energy, or water-energy have long been recognized in both scholarly and policy circles. Notably, energy-water nexus issues were articulated as national priorities in influential US government reports by the Department of Energy [15]. Albeit water-centric, previous frameworks such as Integrated Water Resource Management (IWRM) have long dealt with the nexus approaches and several researchers regard the nexus as a repackaging of these existing integrated frameworks with debated success [16].

The current incarnation of the FEW nexus idea gained attention in the wake of the global food crisis in 2008, which itself was believed to be closely linked to the global energy crisis in 2007 [17,18]. In 2009, the UK's Chief Scientific Adviser to the Government, Professor Beddington, called attention to what he referred to as the 'perfect storm' of problems around water, energy, and food shortages which is likely to lead to public unrest and international conflict in the near future [19]. This coupling between water and energy crises was further highlighted as a global concern in the World Economic Forum report on "Global Risks" in 2011 [10], and gained traction following the Nexus conference in Bonn in 2011, organized as part of the United Nations' 'Rio 2012' conference on sustainable development. Proponents argued that a nexus approach would improve scientific understanding and practical implementation of the complex challenges of sustainable development. Subsequently, a number of prominent international institutions (such as the World Bank, the UN World Water Assessment Programme, the European Commission, the Organization for Economic Co-operation and Development (OECD), and the Global Water Partnership) produced policy and perspective papers on the nexus [20].

Amid this growing interest, several scholars, such as [21] (p. 164), have critiqued the concept as a "buzzword," which they define as a "term that is very much in vogue but whose meaning remains ambiguous among its users." They found in their study that several of their respondents observed that the "nexus is a good idea" but they also reported that it was "not intuitive from the word 'nexus' exactly what it referred to" and that "the practical applications of the term were somewhat confusing" [21] (p. 169). Studies conducted in other parts of the world, such as White et al. [6] in southwestern US, report similar findings. Given these findings, Wichelns [22] asks if the increasing attention on the FEW nexus is warranted from either a research or policy perspective. Wichelns speculates that the FEW nexus concept as a management paradigm will be faced with many of the same impediments that have plagued related efforts, such as Integrated Water Resources Management (IWRM). Critical reflection on the trajectory and impacts of this emerging research area is thus both important and timely.

To advance the scholarly discourse and continued refinement of the FEW nexus literature, we conducted a bibliometric analysis of FEW nexus research literature from 2011, when the Bonn Conference brought the concept of FEW nexus into the international limelight. Our objectives are to assess the trajectory of publications, identify research themes and questions, and explore patterns of links between key terms in the literature in order to understand the growing influence of this concept and the challenges in operationalizing it. Although there are two other bibliometric papers that were recently published on this subject [23,24], our study is different from these in terms of its data sources, time coverage, and methods of analysis. Both of these prior studies used Thomson Reuters' Web of Science database while we used Elsevier's Scopus database, which has been shown to have stronger international/non-English coverage as well as more extensive coverage of social science [25]. The first study [23], covers the linkages between food, energy, and water systems more generally over a 44-year period (1973-2017) while the other study [24], comes closer to our study in terms of its exclusive focus on the FEW nexus and its time coverage (2010-2017). In addition to standard features of bibliometric analyses, a distinguishing feature of our study is that we also conducted a comprehensive thematic analysis of publications through a manual reading and coding of the top 20 most cited papers and all the abstracts in our database. This detailed thematic analysis led us to more comprehensively 
identify the emergent themes and gaps in the integration of concepts, and suggest potential areas for future research.

\section{Methods}

In this study, we applied bibliometric methods to assess the trajectory of research in FEW nexus literature, using the Elsevier Science SCOPUS database. Bibliometric analysis of a field, subject or concept is a descriptive and statistical evaluation for tracking progress and identifying areas for future research [26]. Additionally, bibliometrics is useful for identifying the impact of specific journals, authors, author networks, and individual papers. The Elsevier Science SCOPUS database offers a comprehensive and high-quality catalog for performing this analysis and includes coverage of social science and international records. According to Elsevier, Scopus is the largest abstract and citation database of peer-reviewed literature and several researchers have utilized this database for bibliometric analysis of varied research areas $[27,28]$.

Beyond peer-reviewed literature and gray literature, specifically, conference proceedings are likely to be an essential source for emerging approaches, and thus, an important part of the evidence base for bibliometric analysis of an emerging field. In addition, given that this field's reach and impact extends beyond the scholarly community, the inclusion of gray literature for its breadth and diversity of perspectives could be valuable. However, searching for gray literature can be challenging. Scopus is among the few bibliographic databases that index a variety of types of gray literature, but its coverage of gray literature has been found to be somewhat limited [29]. While we recognize this limitation, we made the choice not to restrict our study to only peer-reviewed publications.

We used "Food, Water and Energy Nexus" and its variations (Water, Food and Energy Nexus; Energy, Food and Water Nexus, etc.) to search titles, abstracts, and keywords for the year 2011 (when Bonn Nexus conference was held) to May 2018. This resulted in a sample of 257 publications for this bibliometric study. We downloaded publications including information about authors, title, publication year, number of citations, journals, author keywords, abstract, digital object identifier (DOI), and references. We then conducted a bibliometric analysis of the 257 publications, using BibExcel 1.0 (Olle Persson, Leuven, Belgium [30], to assess the characteristics of the publications: Type of publication, journal where published, region of study, year of publication and keywords.

To investigate how authors framed their work, we analyzed the frequency of author-specified and title keywords. Given that one objective of nexus scholarship is to integrate knowledge across resource sectors, it is useful to assess how far this literature has advanced in linking concepts and methods across different disciplines and research domains. To examine the linkages among terms used in FEW nexus literature, VOSviewer software (Nees Jan van Eck and Ludo Waltman, Leiden, The Netherlands) was used to create a network map of the co-occurrence of terms extracted from abstracts. VOSviewer extracts terms in the form of noun phrases from abstracts. It defines a noun phrase as "a sequence of one or more consecutive words within a sentence such that the last word in the sequence is a noun and each of the other words is either a noun or an adjective" [31] (p. 32). We compiled and analyzed terms that co-occurred more than 10 times based on their relevance score. We then created a term network map to show co-occurrence and linkages among the terms.

Finally, as FEW nexus research is inherently inter- and trans-disciplinary, we also assessed how the integration of the various disciplines and their respective approaches and methods is reflected in the themes emerging from the top-cited publications. We conducted content analysis of abstracts to identify themes and research foci. Two members of the research team manually read all the abstracts, coded and categorized the themes that emerged. In addition to this analysis based on abstracts, we also conducted a detailed analysis of the entire paper for the 20 top-cited papers to identify research themes, methods used, and main contributions of the paper. This provided deeper insights about the specific themes/ideas that have gained traction in terms of citations as well as served as a consistency check for the BibExcel analysis based only on the abstracts. 


\section{Results}

\subsection{Trends in Publications and Citations}

Figure 1 shows the cumulative increase in publications and citations, starting from the Bonn conference in 2011. It is worth noting that the 2018 trend is not well captured here because the analysis covers only the period up to May 2018.

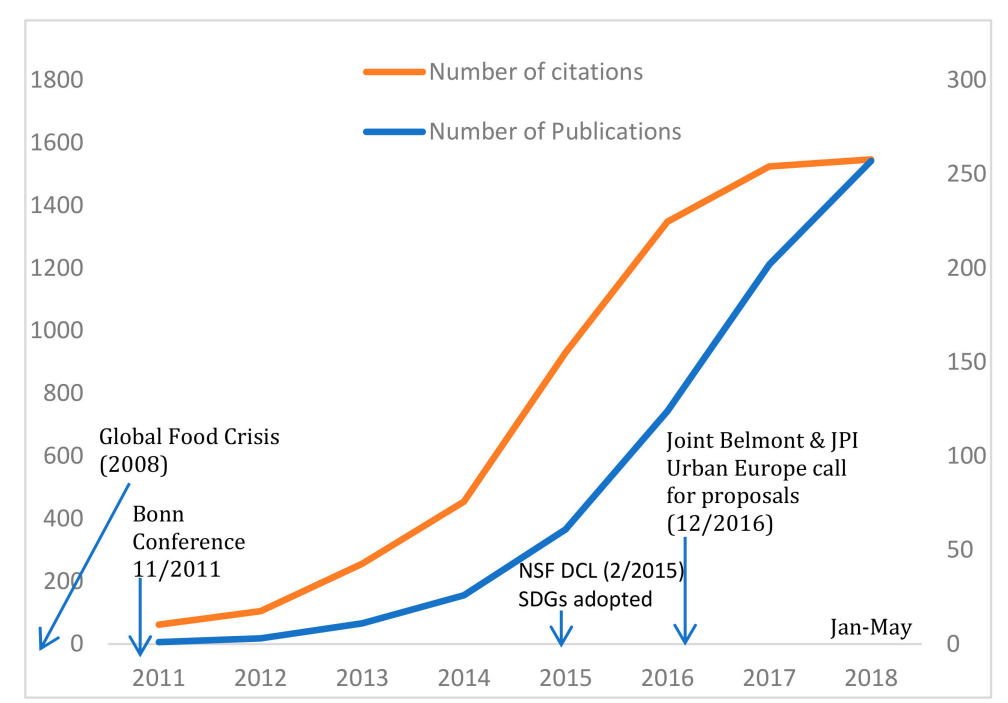

Figure 1. Cumulative trends in publications and citations in FEW nexus literature. Notes: NSF DCL: Dear Colleague Letter from National Science Foundation (NSF) announcing the call for proposals for FEW research workshops.

In order to probe further into the characteristics of these trends, we fitted linear and exponential trend lines on the data for the number of publications, as shown in Figure 2. The exponential trend line provided a better fit (as measured by the R square), thus providing evidence of exponential as opposed to linear growth in the number of publications over the study period.

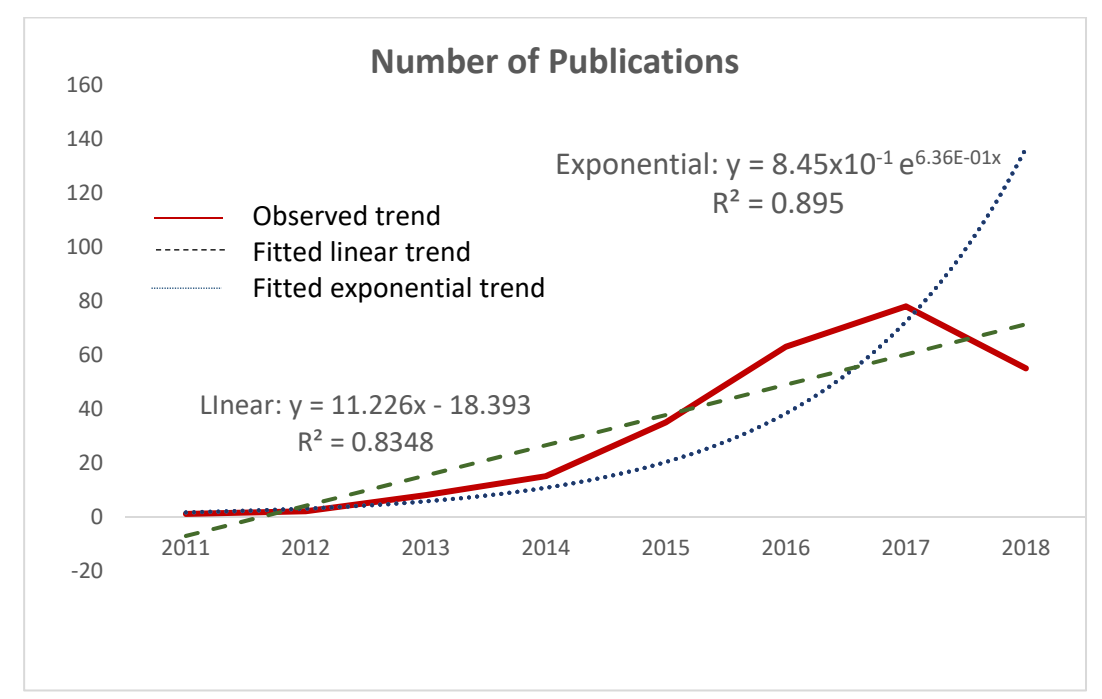

Figure 2. Fitted linear and exponential trend lines for the number of publications.

\subsection{Characteristics of Publications}

To assess the trend of publications, we analyzed the number of publications and citations, journal names, publication types, and study regions. 
Results show a steady increase in the number of publications since 2011, with a sharp upturn observed between 2015 and 2016. This upturn may be attributed to several funding calls and cross-research council initiatives launched around that time [32-37]. The adoption of the United Nation Sustainable Development Goals (SDGs) in September 2015 brought further attention to nexus issues. The names of the top 10 journals where research was published are listed and ranked based on their frequency in Table 1.

Table 1. Top ten journals where FEW nexus research was published.

\begin{tabular}{lllll}
\hline Journal Names & Frequency & Access & IF (5 Years) & IF (2018) \\
\hline Environmental Science and Policy & 15 & Hybrid & 5.127 & 4.816 \\
Journal of Environmental Studies and Sciences & 12 & Hybrid & N/A ** & N/A $^{* *}$ \\
Water & 10 & Open & $2.721^{*}$ & $2.524^{*}$ \\
Applied Energy & 9 & Hybrid & 8.558 & 8.426 \\
Water International & 7 & Hybrid & 2.149 & 1.885 \\
Environmental Progress and Sustainable Energy & 7 & Hybrid & 1.702 & 1.596 \\
Current Opinion in Chemical Engineering & 7 & Hybrid & 4.399 & 4.463 \\
Journal of Cleaner Production & 7 & Hybrid & 7.051 & 6.395 \\
Energy Policy & 6 & Hybrid & 5.458 & 4.88 \\
Sustainability & 6 & Open & 2.801 & 2.592 \\
\hline
\end{tabular}

Source: Thomson Reuters *Water IF is from Journal website **Journal of Environmental Studies and Science IF is Not Available (N/A). Note: IF stands for Impact Factor, Hybrid means open access and subscription-based.

All the listed journals have hybrid access (open and subscription-based), except for the journals Water and Sustainability, which are fully open access. Among all these journals, Environmental Science and Policy had the highest number of publications, followed by the Journal of Environmental Studies and Science, and then Water. Despite their rankings, these journals are not necessarily representative of the varied outlets where nexus works are published. Together, they account for less than $15 \%$ of the 257 publications analyzed. This corresponds with the interdisciplinary nature of the subject, which provides it a wide spectrum of both publication outlets and impact factors. The absence of food-specific journals was unexpected, given the focus of a large part of this literature on the use of energy and water resources in food production.

Of the 257 publications in our sample, around $83 \%$ were peer-reviewed journal articles, followed by book chapters $(8 \%)$, and conference proceedings $(7 \%)$. One hundred and fifty (150) publications were based on place-based case studies. The research locations of these studies, as provided in abstracts, were grouped into world regions as defined by the World Bank [35]. As shown in Table 2, Europe and Central Asia region was the most studied location, followed by South Asia and North America. We acknowledge the potential bias associated with this analysis because authors that did not include the location of their case study in abstracts were not included.

Table 2. Case-study regions of publications.

\begin{tabular}{ll}
\hline Study Region & Frequency \\
\hline Europe and Central Asia & 34 \\
South Asia & 33 \\
North America & 31 \\
Middle East and North Africa & 23 \\
Sub-Saharan Africa & 17 \\
East Asia and Pacific & 8 \\
Latin America and Caribbean & 4
\end{tabular}

Note: Case-study regions were compiled from abstracts. If the authors did not specify their study region in abstract, it was not included in the analysis. 


\subsection{FEW Nexus Keywords Analysis}

Author-specified and title keywords are helpful to understand how authors frame their work and bibliometric analyses generally use these to evaluate emerging research trends [38,39]. Journals typically request that authors provide keywords that are not included in the title. Therefore, we collated title keywords and author-based keywords, then ranked them based on their frequency of occurrence. The keywords 'water,' 'energy' 'food,' and 'nexus' were deleted, as they dominate keywords generated from titles. Table 3 shows the top-ranked keywords.

In Table 3, water-related keywords (water footprints and basin) were ranked the highest in both author-specified and title keyword categories. Water-related keywords also ranked in the top three in the author-specified category. Overall there seems to be a relative dominance of water-related keywords in the table, which provides some support to the observation made in a couple of studies $[22,40]$ about the water-centric framing of nexus studies. It is also interesting to note that the keyword "management" features relatively high in both categories, in contrast to keywords like "governance" and "policy." Critical reviews of nexus literature have pointed to this "managerial framing" of nexus literature, and the relative neglect of socio-institutional and political dimensions of the nexus, as being "highly problematic" [23] (p. 169).

Table 3. Keyword ranking.

\begin{tabular}{cll}
\hline Rank & Author-Specified Keywords & Title Keywords \\
\hline 1 & Water footprint & Basin \\
2 & Hydropower & Urban \\
3 & Water management & Integrated \\
4 & Sustainable development goals & Climate \\
5 & Energy security & Production \\
6 & Green Economy & Sustainable \\
7 & Ecosystems & Model \\
8 & Ecosystem services & Management \\
9 & Virtual water & Challenges \\
10 & Trade-offs & Global \\
11 & Water scarcity & Engineering \\
12 & Life Cycle Assessment & Perspective \\
13 & Environment & Environmental \\
14 & Governance & Governance \\
15 & Optimization & Policy \\
16 & Security & Framework \\
\hline Note: singular use of "food", "water", "energy", and "nexus" as keywords were removed.
\end{tabular}

\subsection{Term Co-Occurrence Network Map}

Starting from the entire text of the abstracts, including 5229 total terms, all words with fewer than ten occurrences were excluded. Only 118 terms met this threshold. Using the relevance scores in VOSviewer, we determined a calculation for the level to which a term is specific and informative or general and uninformative [31]. Only the terms within the highest $60 \%$ of the relevance scores were selected, reducing the number of terms to 72 . The terms were then manually screened to remove words that discussed the research process (e.g., data, research, article) and remove synonyms (e.g., linkage and interconnection, actor and stakeholder). The words food, energy, water, and nexus were also removed from the analysis. Excluding such general terms left us with 32 terms in the network.

Figure 3 shows the relevant terms and their network of co-occurrence. This term co-occurrence network can help us understand the knowledge components and knowledge structure of this field. In general, one observes two types of terms: topical keywords (super set keywords) and specific keywords (subset keywords) [41]. Topical keywords indicate a broad classification of the topics of a field, while specific keywords identify knowledge components and support search and retrieval functions. For example, "interconnection" and "interdependence" are considered supersets and "water 
security" and "ecosystem" are subsets in Figure 3. Statistical analysis is likely to be biased towards topical keywords. This limitation can be overcome by visual analysis, which gives an unbiased view of all keywords [31].

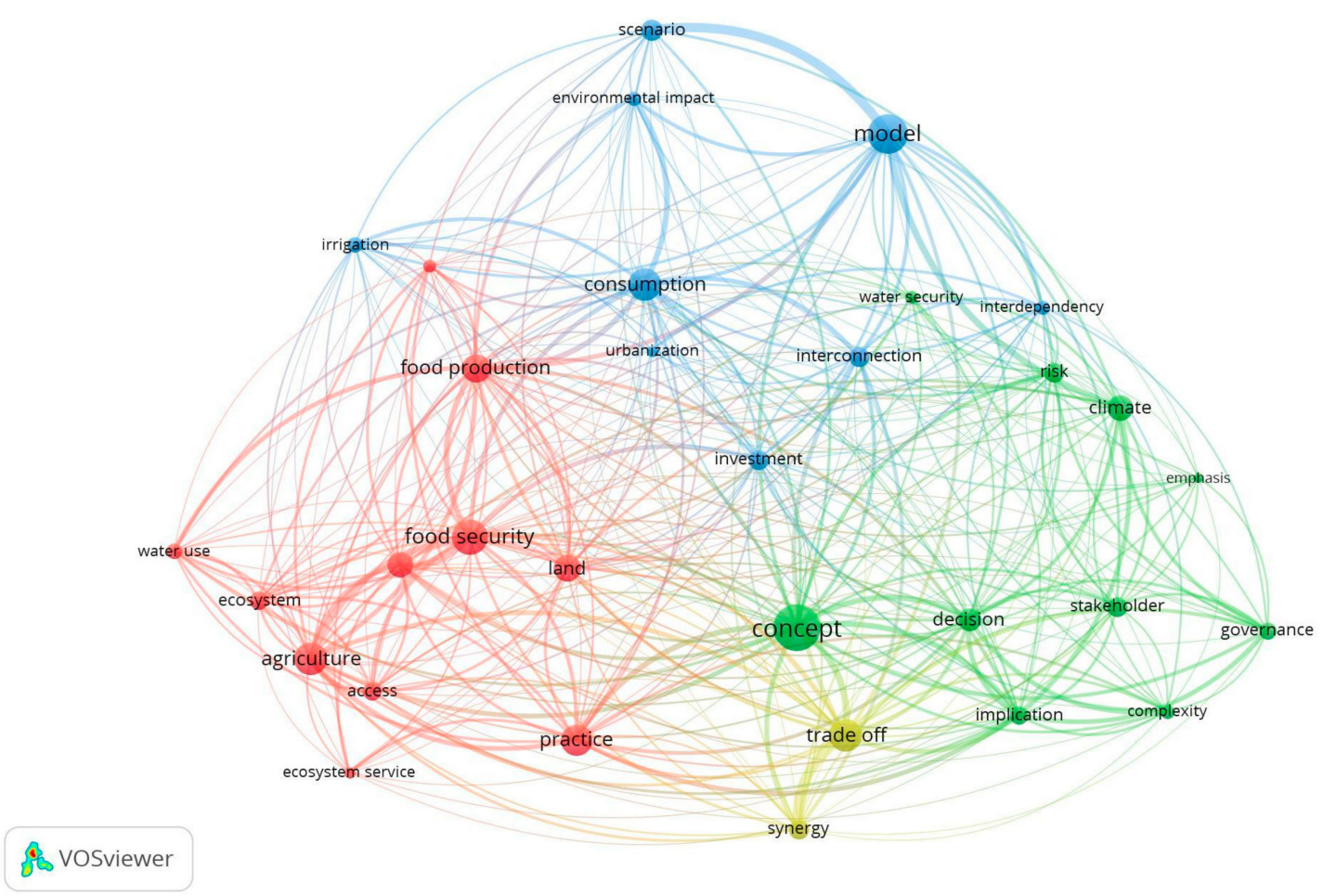

Figure 3. Network of terms from publication abstracts. Source: Authors' Vosviewer analysis of abstracts.

Visual analysis helps researchers identify research directions to advance a scientific field by highlighting terms that are not highly connected to one another as areas for future research, by identifying terms that are missing from the network map or are weakly represented as potential research gaps, and by identifying themes in the clusters to denote sub-themes of the nexus concept. In the visualization, the size of the node indicates the number of abstracts where the term was present. The thickness of the lines between the nodes indicates the level of a direct association between two terms-that is, the number of abstracts in which the two terms co-occurred. VOSviewer also provides distance-based visualizations of bibliometric networks, where the distance between two nodes approximately indicates the relatedness of the nodes [31].

VOSviewer also assigns the nodes in a network to clusters. A cluster is a set of closely related nodes and each node in the network is assigned to exactly one cluster. The number of clusters is determined by a resolution parameter. The higher the value of the parameter, the larger the number of clusters. In the visualization of a bibliometric network, VOSviewer uses colors to indicate the cluster to which a node has been assigned. The terms were clustered into four groups, as shown by the four colors in Figure 3, to reflect how the terms were linked together in the literature. The blue cluster centers on "consumption" and includes other terms such as "environmental impact" and "water scarcity." The theme of this cluster is physical resource interdependencies. The theme of the green cluster is ecological and resource management, with terms such as "water resource," "ecosystems," and "food security." The theme of the red cluster is society and institutions, including terms such as "decision" and "stakeholders." The close connection of these terms with "concept" and "implication" suggests a conceptual focus here as opposed to "modeling" in the blue cluster and "practice" in the green cluster. Finally, the yellow cluster includes only the two terms "synergy" and "trade-off," focusing on the theme of nexus relationships. 
Looking at the network map, we find "investment" as one of the central nodes, with most connections to nodes in the other clusters. While this is suggestive of "investment" being a unifying term across this literature, one must be cautious about how this is interpreted. It is possible that "investment" gets mentioned frequently in abstracts as part of a high-level conclusion statement (such as: "more investment is needed") even when "investment" is not a central focus of the analysis. We return to these varied interpretations in greater depth in the conclusions section.

It is also interesting to note that "governance" lies at the edge of the map, with weak connections to "model," "scenario" and "ecosystem services." This suggests that governance based research in this literature is not well integrated with modeling- and scenarios-based work. These findings also corroborate the observation made in some other critical reviews that the FEW nexus literature, which had its origins in the World Economic Forum's 2011 report and subsequent reports of several international development organizations, has tended to focus more on techno-economic and managerial approaches than governance and socio-political approaches [22-24].

\subsection{Research Themes and Associated Methods}

Building on the keyword and term analysis, we turn to the identification of key themes in the literature. We manually read through the 257 publication abstracts to identify key themes and grouped together those concepts that are analyzed within a common theoretical paradigm/framework. Given that abstracts are stand-alone summaries that provide an overview of the work, we assume that authors will carefully construct these to highlight the salient research themes, methods, and findings. However, we acknowledge that there may be cases where the abstract is not truly representative of the work. Thus, for a subset of the top 20 most cited papers, we also read through the entire paper to identify key themes. This detailed analysis of the top 20 most cited papers also helps identify which authors and/or themes have gained most traction in the literature. We report the results of this analysis in the next section.

Table 4 reports on the results from the analysis of abstracts of our full sample of 257 publications. This table lists the different themes we identified, the research questions that animate them, and the approaches and methods used most frequently to address those questions. A more detailed breakdown of FEW publications by methods is given in Albrecht et al. [12].

Table 4. Identification of key themes, research questions, and methods.

\begin{tabular}{|c|c|c|c|}
\hline $\begin{array}{l}\text { Key Theme(s) and Related } \\
\text { Influential Papers: }\end{array}$ & Theoretical Framing & $\begin{array}{l}\text { Key Research } \\
\text { Questions }\end{array}$ & $\begin{array}{l}\text { Key Approaches/ } \\
\text { Methods Used }\end{array}$ \\
\hline Resource interdependencies & $\begin{array}{l}\text { Integrated Assessment, } \\
\text { process system } \\
\text { engineering, chemical } \\
\text { engineering }\end{array}$ & $\begin{array}{l}\text { How can FEW resource } \\
\text { efficiency be enhanced, } \\
\text { given resource } \\
\text { interdependencies? How } \\
\text { to prioritize investments } \\
\text { under alternative } \\
\text { scenarios to co-balance } \\
\text { benefits? }\end{array}$ & $\begin{array}{l}\text { Quantitative modeling: } \\
\text { Foot printing, life cycle, } \\
\text { input-output, supply } \\
\text { chain analysis, statistical } \\
\text { modeling, scenario } \\
\text { analysis }\end{array}$ \\
\hline $\begin{array}{l}\text { FEW security and climate } \\
\text { resilience }\end{array}$ & $\begin{array}{l}\text { Human security. Food } \\
\text { security.Vulnerability, } \\
\text { adaptation, and } \\
\text { resilience }\end{array}$ & $\begin{array}{l}\text { What are the key drivers } \\
\text { of FEW security? (E.g. } \\
\text { climate change, } \\
\text { population growth, land } \\
\text { use change, } \\
\text { urbanization). How can } \\
\text { resilience of FEW } \\
\text { systems be enhanced? }\end{array}$ & $\begin{array}{l}\text { Mixed methods: Risk } \\
\text { and vulnerability } \\
\text { analysis, scenario } \\
\text { analysis }\end{array}$ \\
\hline
\end{tabular}


Table 4. Cont.

\begin{tabular}{|c|c|c|c|}
\hline $\begin{array}{l}\text { Key Theme(s) and Related } \\
\text { Influential Papers: }\end{array}$ & Theoretical Framing & $\begin{array}{l}\text { Key Research } \\
\text { Questions }\end{array}$ & $\begin{array}{l}\text { Key Approaches/ } \\
\text { Methods Used }\end{array}$ \\
\hline $\begin{array}{l}\text { Sustainable Development } \\
\text { Goals (SDGs) }\end{array}$ & Sustainable development & $\begin{array}{l}\text { How FEW nexus (as an } \\
\text { integrated approach) can } \\
\text { advance the SDGs, } \\
\text { mostly in the context of } \\
\text { low and middle-income } \\
\text { countries? }\end{array}$ & $\begin{array}{l}\text { Mixed methods: } \\
\text { Situating FEW systems } \\
\text { within a development } \\
\text { context of high poverty, } \\
\text { limited livelihood } \\
\text { options and weak } \\
\text { institutions }\end{array}$ \\
\hline $\begin{array}{l}\text { Ecosystem services, } \\
\text { environmental management }\end{array}$ & Ecosystem services & $\begin{array}{l}\text { How do ecosystem } \\
\text { services impact and are } \\
\text { impacted by FEW } \\
\text { systems? }\end{array}$ & $\begin{array}{l}\text { Quantitative methods: } \\
\text { Spatially explicit } \\
\text { ecosystem modeling }\end{array}$ \\
\hline $\begin{array}{l}\text { Governance, intersectoral } \\
\text { integration, collaborations }\end{array}$ & $\begin{array}{l}\text { Institutional analysis, } \\
\text { policy analysis }\end{array}$ & $\begin{array}{l}\text { How can the } \\
\text { understanding of FEW } \\
\text { nexus contribute } \\
\text { towards policy } \\
\text { integration, intersectoral } \\
\text { collaborations and } \\
\text { coordination, decision } \\
\text { support? }\end{array}$ & $\begin{array}{l}\text { Mixed methods: } \\
\text { Interviews, surveys, case } \\
\text { studies, policy analysis, } \\
\text { institutional analysis, } \\
\text { stakeholder engagement, } \\
\text { decision making }\end{array}$ \\
\hline $\begin{array}{l}\text { New technologies and } \\
\text { innovations. }\end{array}$ & Technology and society & $\begin{array}{l}\text { What are the synergies } \\
\text { and trade-offs associated } \\
\text { with different FEW } \\
\text { resource-related } \\
\text { innovations? What are } \\
\text { the economic benefits } \\
\text { associated with these } \\
\text { innovations? }\end{array}$ & $\begin{array}{l}\text { Technology adoption } \\
\text { and assessment models }\end{array}$ \\
\hline
\end{tabular}

\subsubsection{Resource Interdependencies}

As shown in Figure 4, the dominant theme in this literature relates to examining the interdependencies among the FEW resources. Early papers in this literature called for the need to better understand the complex interactions among these resource systems in order to "to co-balance the costs of tradeoffs and identify the synergies" [8] (p. 618). Numerous studies sought to understand synergies and trade-offs using simulation models, system dynamics models, case studies and other tools [42-51]. The frameworks used within this theme were, for the most part, based on disciplinary perspectives such as chemical engineering, chemistry [52], and process system engineering [53]. Some papers used Integrated Assessment models [49,54,55].

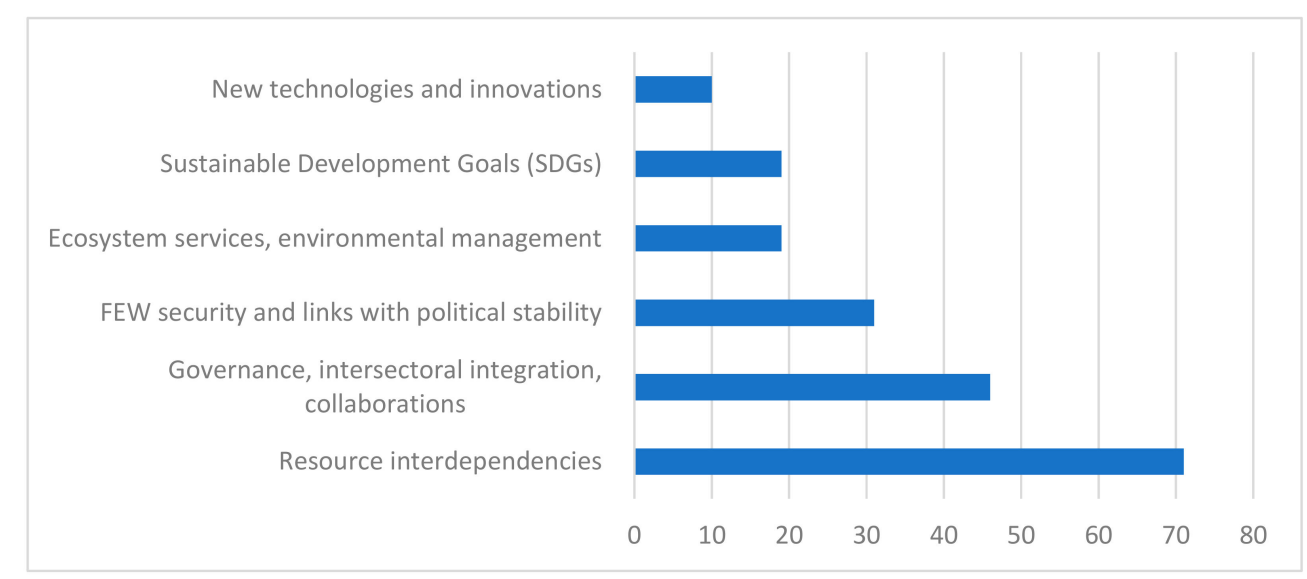

Figure 4. Number of publications focused on the six identified themes. 


\subsubsection{FEW Security and Links with Climate Change}

Climate change, adaptation to climate-induced changes, and the implications on FEW security came up in many articles $[42,56]$. Biofuel production policy was of primary concern as it has the potential to have severe impacts on the FEW nexus system in terms of competition for land that should be put under food production. Much of this work coalesced around the need to address some of these social, economic, and environmental impacts to enhance resilience and adaptation to climate change in developing countries [57-59].

\subsubsection{Role of Nexus Perspective in Enhancing the Sustainable Development Goals (SDGs)}

The utility of the nexus perspective in enhancing SDGs was stressed in many of the abstracts reviewed, with one of the most influential papers stating that the "Sustainable Development Goals (SDGs) represent a globally significant test for the implementation of nexus thinking" [8]. The nexus concept was also promoted as providing an integrated assessment approach for framing, studying, and solving development issues such as climate change, water and air quality, land, conflicts and public health [49]. Bleischwitz et al. [60] and Gallagher et al. [61], for example, suggested that the FEW nexus acts as a bridge concept between the separate and fragmented SGDs. Others posited that it is a viable concept for understanding the risks of resource allocation decisions and their impacts on the disadvantaged populations. However, many of these articles were skeptical about the ability of the FEW concept to achieve the SDG goal of promoting security of these three resources and consequently eradicating poverty because of the focus on resource efficiency for continual economic development.

\subsubsection{Ecosystem Services and Environmental Management}

Adopting a nexus perspective for resource management was also proposed as a strategy to address ecosystem problems and depletion. For instance, Bell et al. [62] argued that this concept could be a good tool for understanding and solving water quality issues related to agricultural activities. Others argued that the nexus perspective was not just a tool, but also a transition pathway to a green economy that advocates for valuing ecosystem services [63,64]. Leese and Meisch [65], however, were concerned about promoting the FEW nexus as a means for obtaining a green economy over resource security. They were particularly worried about how this shift might impact the global concern of alleviating poverty. Still, others [66] emphasized the role of ecosystem services in sustaining FEW resource security, encouraging more research in this area.

\subsubsection{Governance, Intersectoral Integration and Collaborations}

A few studies used a governance lens to examine the perceptions of different stakeholders [6] and explore barriers to greater intersectoral integration and collaborations in managing FEW resources [67-69]. Portney et al. [70] examined public awareness of FEW nexus connections and the extent to which such awareness is associated with support for public policies designed to address these interconnections. A couple of studies also examined the social and political relations between the FEW sectors that can pose rigidities and limit the possibilities for greater integration [71,72].

\subsubsection{New Technologies and Innovations}

A few publications looked at new technologies and innovations that leverage the synergies among FEW resources to increase resource efficiency or reduce/reuse waste. These included waste to power technologies [73], bioenergy production [74], raised-bed plasticulture innovation [75], and recycling of wastewater for irrigation [76-78]. There is a need for more studies showcasing innovations at different levels and exploring new ones to address the identified disconnect between FEW resources' management. 


\subsection{Top 20 Most Cited Papers}

Given that there may be cases where the abstract is not truly representative of the work, for a subset of the top 20 most cited papers, we read through the entire paper to get some insights on what factors might explain the influence of these highly cited papers and which key themes are gaining the most traction. As shown in Table 5, all of these top-cited papers were published in the period from 2011 to 2016, with around one-third published before 2015, when there was a spike in the number of publications. These early papers were likely foundational in terms of laying the conceptual and methodological underpinnings of this literature. It is also interesting to note that the research reported in a majority of these top-cited papers was at the regional or global scale, only two papers reported research at the city scale.

Table 5. Top 20 most cited articles.

\begin{tabular}{|c|c|c|c|c|c|c|c|}
\hline No & Author (s) & Year & Journal/Publisher & Citations & Themes & Methods & $\begin{array}{l}\text { Spatial } \\
\text { Scales }\end{array}$ \\
\hline 1 & Ringler et al. & 2013 & $\begin{array}{l}\text { Current Opinion in } \\
\text { Environmental } \\
\text { Sustainability }\end{array}$ & 101 & $\begin{array}{c}\text { Sustainable Development } \\
\text { Goals, Resource } \\
\text { Interdependencies }\end{array}$ & Review & Global \\
\hline 2 & Rasul & 2014 & $\begin{array}{l}\text { Environmental Science } \\
\text { and Policy }\end{array}$ & 80 & $\begin{array}{l}\text { Governance, Intersectoral } \\
\text { Integration, Collaboration }\end{array}$ & Case study & Regional \\
\hline 3 & Kenway et al. & 2011 & $\begin{array}{l}\text { Water Science and } \\
\text { Technology }\end{array}$ & 62 & $\begin{array}{c}\text { Resource } \\
\text { Interdependencies }\end{array}$ & $\begin{array}{l}\text { Case study, } \\
\text { review }\end{array}$ & City \\
\hline 4 & Biggs et al. & 2015 & $\begin{array}{c}\text { Environmental Science } \\
\text { and Policy }\end{array}$ & 57 & $\begin{array}{c}\text { Sustainable Development } \\
\text { Goals }\end{array}$ & Review & Global \\
\hline 5 & $\begin{array}{c}\text { Villarroel } \\
\text { Walker et al. }\end{array}$ & 2014 & $\begin{array}{c}\text { Journal of Environmental } \\
\text { Management }\end{array}$ & 51 & $\begin{array}{l}\text { New Technologies and } \\
\text { Innovations }\end{array}$ & $\begin{array}{l}\text { Multi-sectoral } \\
\text { Systems } \\
\text { Analysis }\end{array}$ & Cities \\
\hline 6 & Lawford et al. & 2013 & $\begin{array}{l}\text { Current Opinion in } \\
\text { Environmental } \\
\text { Sustainability }\end{array}$ & 41 & $\begin{array}{c}\text { FEW security; } \\
\text { Governance, Intersectoral, } \\
\text { Integration } \\
\text { Collaborations }\end{array}$ & Case study & Regional \\
\hline 7 & Conway et al. & 2015 & Nature Climate Change & 38 & $\begin{array}{l}\text { FEW Security and } \\
\text { Climate Resilience }\end{array}$ & Case study & Regional \\
\hline 8 & Finley et al. & 2014 & $\begin{array}{l}\text { Journal of Agricultural } \\
\text { and Food Chemistry }\end{array}$ & 35 & $\begin{array}{l}\text { FEW Security/New } \\
\text { Technologies and } \\
\text { Innovations }\end{array}$ & Case study & National \\
\hline 9 & Garcia et al. & 2014 & $\begin{array}{c}\text { Computers and Chemical } \\
\text { Engineering }\end{array}$ & 34 & $\begin{array}{c}\text { Resource } \\
\text { Interdependencies }\end{array}$ & Review & General \\
\hline 10 & Smajgl et al. & 2016 & Journal of Hydrology & 32 & $\begin{array}{l}\text { Governance, Intersectoral } \\
\text { Integration, Collaboration }\end{array}$ & $\begin{array}{l}\text { Case study, } \\
\text { Field research }\end{array}$ & Regional \\
\hline 11 & Jarvie et al. & 2015 & $\begin{array}{c}\text { Journal of environmental } \\
\text { quality }\end{array}$ & 30 & $\begin{array}{c}\text { Ecosystem Services, } \\
\text { Environmental } \\
\text { Management }\end{array}$ & Case study & National \\
\hline 12 & Leck et al. & 2015 & Geography Compass & 29 & $\begin{array}{l}\text { Governance, Intersectoral } \\
\text { Integration, Collaboration }\end{array}$ & Review & Global \\
\hline 13 & Allan et al. & 2015 & $\begin{array}{c}\text { International Journal of } \\
\text { Water Resources } \\
\text { Development }\end{array}$ & 28 & $\begin{array}{l}\text { Governance, Intersectoral } \\
\text { Integration, Collaboration }\end{array}$ & Review & Global \\
\hline 14 & Scott et al. & 2015 & $\begin{array}{l}\text { Book: "Governing the } \\
\text { Nexus: Water, Soil and } \\
\text { Waste Resources } \\
\text { Considering Global } \\
\text { Change" }\end{array}$ & 27 & $\begin{array}{l}\text { Resource } \\
\text { interdependencies, } \\
\text { Governance }\end{array}$ & $\begin{array}{l}\text { Review, Case } \\
\text { study }\end{array}$ & Global \\
\hline 15 & Vanham, & 2016 & Ecosystem Services & 25 & $\begin{array}{c}\text { Resource } \\
\text { Interdependencies }\end{array}$ & Review & Global \\
\hline 16 & $\begin{array}{l}\text { Daher and } \\
\text { Mohtar }\end{array}$ & 2015 & Water International & 24 & $\begin{array}{c}\text { Resource } \\
\text { Interdependencies/Coupling }\end{array}$ & $\begin{array}{l}\text { Case study, } \\
\text { Modelling }\end{array}$ & National \\
\hline 17 & $\begin{array}{l}\text { Cairns and } \\
\text { Krzywoszynska }\end{array}$ & 2016 & $\begin{array}{c}\text { Environmental Science } \\
\text { and Policy }\end{array}$ & 23 & $\begin{array}{c}\text { Resource } \\
\text { Interdependencies, } \\
\text { Governance }\end{array}$ & Review & National \\
\hline 19 & Muller & 2015 & Water Alternatives & 22 & $\begin{array}{l}\text { Sustainable Development } \\
\text { Goals/Governance }\end{array}$ & Review & Global \\
\hline 18 & Foran & 2015 & Water Alternatives & 22 & $\begin{array}{l}\text { Governance, Intersectoral } \\
\text { Integration, Collaboration }\end{array}$ & $\begin{array}{l}\text { Review, Case } \\
\text { study }\end{array}$ & Regional \\
\hline 20 & Ozturk & 2015 & Energy & 22 & $\begin{array}{l}\text { Ecosystem Services, } \\
\text { Environmental } \\
\text { Management }\end{array}$ & $\begin{array}{l}\text { Dynamic } \\
\text { Economic } \\
\text { Modeling }\end{array}$ & $\begin{array}{l}\text { Transnational } \\
\text { (BRICS) }\end{array}$ \\
\hline
\end{tabular}


We found that the themes in these top-cited papers span the five key thematic areas we identified in the previous sub-section. As was the case for the full sample, we found that for this subset also 'resource interdependencies' was the dominant theme $[8,9,14,21,53,79,80]$. Next is the theme of 'governance, intersectoral integration, collaboration' [5,66,81-84]. A few papers were thematically focused on Sustainable Development Goals (SDGs) and discussed the capacity of FEW nexus to deliver on resource security globally $[1,8,40]$. Two papers focused on the theme of FEW security and climate change [81,85], arguing that there is a need for adaptation measures and capacity building to mitigate the negative impacts that are being currently experienced in some regions of the world. Ozturk [86] and Jarvie et al. [57] focused on ecosystem services/environmental management themes in managing FEW from a nexus perspective. Walker [78] was the only paper focused on new technologies and innovation to achieve efficiency and security of FEW resources. A few papers have also noted the relative dominance of resource efficiency goals over the security of the poor globally $[1,8,40,63]$.

\section{Discussion and Conclusions}

In this section, we discuss the major results from the bibliometric analysis regarding trends in publications, major research questions and themes, and the current state of integration across disciplines and methods, in the broader context of the key global drivers and funding calls that have shaped how this literature has evolved. We also discuss the key challenges related to scaling mismatches in data and governance that have influenced how far nexus thinking has been translated into nexus action. We end with some recommendations for future avenues of research.

The idea of a nexus among resource sectors is not new. Concepts such as water-energy nexus or land-water nexus have a long history of scholarship. However, in order to understand the conceptualization and trajectory of FEW nexus thinking over the past decade, it is worth pointing to three major global/regional scale drivers that framed the urgency for new thinking: global attention to resource interlinkages due to the coupling of FEW resource crises in 2008 with the global financial recession, the global and regional scale resource supply crises exacerbated by climate change, and the long frustration with sector-driven management strategies.

Responding to this globally articulated need, major funding agencies in Europe, UK, and the US issued funding calls around 2015 to promote research in this area. In the original Dear Colleague Letter (DCL) [32] issued by NSF in 2015, the focus was on understanding complex coupled systems that require new or enhanced partnerships. In this DCL, the NSF requested proposals to stimulate discussion and visions about how research communities could collaborate to bridge physical, natural, and social/behavioral processes to understand the food-energy-water nexus, specifically calling out visualization as a mechanism for supporting this understanding. The workshops that originated from this DCL initiated the first Innovations in Food, Energy, Water Systems (INFEWS) call for proposals, where four research tracks were solicited: (1) FEW System Modeling, (2) Visualization and Decision support for Cyber-Human-Physical Systems at the FEW Nexus, (3) Research to Enable Innovative Solutions, and (4) Education and Workforce Development. The heavy focus on modeling and natural sciences that we discussed earlier in the paper can be traced back, at least in part, to the delineation of these research tracks in the NSF call.

Several recent reviews of this literature have assessed how far the call for greater integration across sectors, disciplines, and methods has been achieved. Our analyses, as well as several other reviews, have pointed to the relative dominance of water in FEW thinking, tracing it back to the strong influence of previous frameworks, such as IWRM, in shaping this literature. In general, it seems that the specific lens taken (whether water, energy or food) has a strong influence on how the interactions are modeled and this has led some to question whether there is consistency in integration [87]. For example, nexus assessments of food production consider energy and water as inputs, whereas, through a water lens, food and energy production are both primary users [88]. Similarly, in terms of research methods, integration across disciplines has been achieved to some extent, but there remain significant limitations. In a recent review of research methods in the FEW nexus literature, Albrecht et al. [12] found the use of 
social science methods to be limited to only around one-quarter of the FEW nexus publications. They also found that nexus methods are confined to disciplinary silos, with only around one-quarter of publications that combine methods from diverse disciplines and less than one-fifth that draw upon both quantitative and qualitative approaches.

A major constraint to achieving integration in this literature is the lack of consistent data availability across scales and sectors. Whereas at the national or transnational level, data is often available on open access data platforms (e.g., Food and Agricultural Organization (FAO) databases: FAOSTAT and AQUASTAT; and the United Nations Statistics Division (UNSD) databases) at smaller scales, data confidentiality and commercial confidence issues become major impediments. As McGrane et al. [87] (p. 8) observe, "at small scales, the nexus can almost be conceived as a 'black box' from a data perspective, whereby the inputs and outputs are identifiable, but it is often the in-between connections that remain poorly elucidated." They further point out that among the three FEW sectors, food consumption and waste data remain the most elusive at local scales. These data limitations have held back progress in the implementation of many of the integrative frameworks proposed in the literature. The emergence of new monitoring technologies could enable ways to capture data at increasingly higher spatial and temporal resolutions, provided these data are not prohibitively expensive or institutionally exclusive.

Beyond data limitations, the more fundamental hindrance to the translation of nexus studies can be traced to the problem of governance scale mismatches. There remains a disconnect between the spatial scale at which decisions are made, and the scale at which FEW production and consumption are being conceptualized and modeled. Decisions are made at multiple governance scales (from local to regional to national to global) and at various (overlapping) geographic scales (city, county, state, watershed), and yet, most FEW models pick a single geographic and governance scale and fail to incorporate or account for cross-scalar interactions and feedbacks. This points to the need for a hierarchical framework that integrates across scales and varied perspectives [87].

These unresolved data and governance challenges have led to the frustration that although the nexus approach has attracted a lot of scholarly attention, it has yielded limited action [21]. It is worth noting here that in the NSF DCL [33], only track 2 (visualization and decision support) explicitly referenced policy as a key research component. In order to build a decision support system, validated models that can generate data to be utilized in the decision support system are needed. Since modeling efforts have been the predominant focus of literature in the FEW nexus, the shift from well-established models into the policy domain can be a heavy lift. These challenges have led to limited research in the policy, visualization, and decision support system area of the FEW nexus, which was further exacerbated by the removal of the visualization and decision support track in the NSF call for INFEWS proposals in 2018.

As FEW nexus policies challenge current governance configurations in order to promote cross-sectoral integration and management, the capacity to engage and coordinate at a deeper level with a wide range of sectoral organizations whose interests are diverse and often conflicting-is critical. Decision support tools and models need to be perceived as credible, salient, and legitimate [89], and the framing of key concepts and uncertainties in the models affect how decision-makers perceive the validity and usefulness of model-based decision support tools [90,91]. In this context, some fundamental questions related to FEW nexus policy revolve around the issues of policy capacity and the instruments of cross-sectoral integration. Here, we think that serious engagement with public administration literature [72,92], particularly around issues of policy coherence and challenges at the operational level, could be very beneficial.

To conclude, although the FEW nexus literature has seen tremendous growth over the past decade, we remain a considerable distance away from holistic frameworks and tools that incorporate all aspects of the nexus, stakeholder inputs, policy perspectives, and future scenarios for change. Among these different perspectives, the lack of governance, and more broadly speaking, social science perspectives, is especially disturbing, as was evident in our network map. Many of the existing frameworks remain 
theoretical and require extensive data inputs, as well as a serious engagement with diverse stakeholders, in order to make the transition from nexus thinking to nexus action.

Author Contributions: A.K.O. retrieved the data, conducted the bibliometric analysis and wrote the first draft of the paper. R.M.A. refined the draft, wrote the discussion and conclusion section, and led the integration of revisions and edits from her co-authors. D.D.W. contributed by editing the paper as well as refining parts, especially the introductory and concluding sections. J.L.J. helped with editing and contributed to refinement of the section on term co-occurrence network map. R.M., G.M. and H.S.S. contributed to the discussion and conclusion section. All authors have read and agreed to the published version of the manuscript.

Acknowledgments: This research was supported by the National Science Foundation: Award no. CNS-1639227, INFEWS/T2: Flexible Model Compositions and Visual Representations for Planning and Policy Decisions at the Sub-regional level of the food-energy-water nexus.

Conflicts of Interest: The authors declare no conflict of interest. The funding sponsors had no role in the design of the study; in the collection, analyses, or interpretation of data; in the writing of the manuscript, and in the decision to publish the results.

\section{References}

1. Biggs, E.M.; Bruce, E.; Boruff, B.; Duncan, J.M.A.; Horsley, J.; Pauli, N.; McNeill, K.; Neef, A.; Van Ogtrop, F.; Curnow, J.; et al. Sustainable development and the water-energy-food nexus: A perspective on livelihoods. Environ. Sci. Policy 2015, 54, 389-397. [CrossRef]

2. Rasul, G.; Sharma, B. Water, food, and energy nexus in south Asia: Implications for adaption to climate change. In Anonymous Handbook of Climate Change Adaptation; Springer Nature: Berlin, Germany, 2015; pp. 1329-1350.

3. Kumar, M.D.; Bassi, N.; Narayanamoorthy, A.; Sivamohan, M.V.K. The Water, Energy and Food Security Nexus: Lessons from India for Development, in Anonymous the Water, Energy and Food Security Nexus: Lessons from India for Development; Routledge: New York, NY, USA, 2014; pp. 1-224.

4. World Economic Forum (WEF). WEF Global Risks. Available online: https://www.weforum.org/global-risks (accessed on 12 December 2019).

5. Leck, H.; Conway, D.; Bradshaw, M.; Rees, J. Tracing the Water-Energy-Food Nexus: Description, Theory and Practice. Geogr. Compass 2015, 9, 445-460. [CrossRef]

6. White, D.D.; Jones, J.L.; Maciejewski, R.; Aggarwal, R.; Mascaro, G. Stakeholder Analysis for the Food-Energy-Water Nexus in Phoenix, Arizona: Implications for Nexus Governance. Sustainability 2017, 9, 2204. [CrossRef]

7. Hoff, H. Understanding the Nexus. In Background Paper for the Bonn 2011 Conference: The Water, Energy and Food Security Nexus; Stockholm Environment Institute (SEI): Stockholm, Sweden, 2011.

8. Ringler, C.; Bhaduri, A.; Lawford, R. The nexus across water, energy, land and food (WELF): Potential for improved resource use efficiency? Curr. Opin. Environ. Sustain. 2013, 5, 617-624. [CrossRef]

9. Kenway, S.J.; Lant, P.A.; Priestley, A.; Daniels, P. The connection between water and energy in cities: A review. Water Sci. Technol. 2011, 63, 1983-1990. [CrossRef] [PubMed]

10. World Economic Forum (WEF). Global Risks 2011, Sixth Edition: An Initiative of the Risk Response Network; World Economic Forum: Cologny/Geneva, Switzerland, 2011.

11. Al-Ansari, T.; Korre, A.; Nie, Z.; Shah, N. Development of a life cycle assessment model for the analysis of the energy, water and food nexus. Comput. Aided Chem. Eng. 2014, 33, 1039-1044.

12. Albrecht, T.R.; Cootof, A.; Scott, C.A. The Water-Energy-Food Nexus: A systematic review of methods of nexus assessment. Environ. Res. Lett. 2018, 13, 4. [CrossRef]

13. Gleick, P.H. Water and energy. Annu. Rev. Energy Environ. 1994, 19, 267-299. [CrossRef]

14. Scott, C.A.; Kurian, M.; Wescoat, J.L., Jr. The Water-Energy-Food Nexus: Enhancing Adaptive Capacity to Complex Global Challenges. In Governing the Nexus; Springer: Cham, Switzerland, 2015; pp. 15-38.

15. Department of Energy (DOE). Energy Demands on Water Resources: Report to Congress on the Interdependency of Energy and Water; U.S. Department of Energy: Washington, DC, USA, 2006. Available online: http://www.circleofblue.org/wp-content/uploads/2010/09/121-RptToCongress-EWwEIAcommentsFINAL2.pdf (accessed on 23 October 2017).

16. Benson, D.; Gain, A.K.; Rouillard, J.J. Water governance in a comparative perspective: From IWRM to a 'nexus' approach? Water Altern. 2015, 8, 756-773. 
17. Cribb, J. The Coming Famine: The Global Food Crisis and What We Can Do to Avoid It; University of California Press: Berkley, CA, USA, 2010.

18. Spiertz, J.H.J.; Ewert, F. Crop production and resource use to meet the growing demand for food, feed and fuel: Opportunities and constraints. Njas-Wagening. J. Life Sci. 2009, 56, 281-300. [CrossRef]

19. Beddington, J. Food, energy, water and the climate: A perfect storm of global events? Proceedings of the Conference Presentation Given to the Sustainable Development UK Annual Conference, QEII Conference Centre, London, UK, 19 March 2009. Available online: https://webarchive.nationalarchives.gov. uk/20121206120858 (accessed on 30 August 2019).

20. Allouche, J.; Middleton, C.; Gyawali, D. Technical veil, hidden politics: Interrogating the power linkages behind the nexus. Water Altern. 2015, 8, 610-626.

21. Cairns, R.; Krzywoszynska, A. Anatomy of a buzzword: The emergence of 'the water-energy-food nexus' in UK natural resource debates. Environ. Sci. Policy 2016, 64, 164-170. [CrossRef]

22. Wichelns, D. The water-energy-food nexus: Is the increasing attention warranted, from either a research or policy perspective? Environ. Sci. Policy 2017, 69, 113-123. [CrossRef]

23. Newell, J.P.; Goldstein, B.; Foster, A. A 40-year review of food-energy-water nexus literature and its application to the urban scale. Environ. Res. Lett. 2019, 14, 7. [CrossRef]

24. Chen, D.; Zhang, P.; Luo, Z.; Zhang, D.; Bi, B.; Cao, X. Recent progress on the water-energy-food nexus using bibliometric analysis. Curr. Sci. 2019, 117, 4. [CrossRef]

25. Wagner, B. A Practical Comparison of Scopus and Web of Science Core Collection. 2015. Available online: https: //ubir.buffalo.edu/xmlui/bitstream/handle/10477/38568/Scopus\%20vs\%20WOS.pdf?sequence=1 (accessed on 19 January 2020).

26. Armfield, N.R.; Edirippulige, S.; Caffery, L.J.; Bradford, N.K.; Grey, J.W.; Smith, A.C. Telemedicine-a bibliometric and content analysis of 17,932 publication records. Int. J. Med. Inf. 2014, 83, 715-725. [CrossRef]

27. López-Illescas, C.; De Moya-Anegón, F.; Moed, H.F. Coverage and citation impact of oncological journals in the Web of Science and Scopus. J. Informetr. 2008, 2, 304-316. [CrossRef]

28. Sánchez, A.D.; Del Río Rama, M.; García, J.Á. Bibliometric analysis of publications on wine tourism in the databases Scopus and WoS. Eur. Res. Manag. Bus. Econ. 2017, 23, 8-15. [CrossRef]

29. Bonato, S. Google Scholar and Scopus for finding gray literature publications. J. Med. Libr. Assoc. 2016, 104, 252-254.

30. Persson, O.; Danell, R.; Schneider, J.W. How to Use Bibexcel for Various Types of Bibliometric Analysis. Celebrating Scholarly Communication Studies: A Festschrift for Olle Persson at His 60th Birthday. Int. Soc. Scientometr. Informetr. 2009, 5, 9-24.

31. Van Eck, N.; Waltman, L. VOSviewer Manual; Univeristeit Leiden: Leiden, The Netherlands, 2013.

32. Engineering and Physical Sciences Research Council (EPSRC). Sandpit Water Energy Food Nexus 19-23 January. 2015. Available online: https://webarchive.nationalarchives.gov.uk/20170721181649/https://www. epsrc.ac.uk/files/funding/calls/2014/sandpitwaterenergyfoodnexus/ (accessed on 11 December 2019).

33. National Science Foundation (NSF). Dear Colleague Letter: SEES: Interactions of Food Systems with Water and Energy Systems. 2015. Available online: https://www.nsf.gov/pubs/2015/nsf15040/nsf15040.jsp (accessed on 11 December 2019).

34. Economic Social Research Council (ESRC)/Newton Fund. Healthy Urban Living and the Social Science of the Food-Water-Energy Nexus: UK-Brazil Calls for Collaborative Research. Available online: http://www.facepe.br/wp-content/uploads/2015/08/Healthy-Urban-Living-and-the-Social-Science-of-theFood-Water-Energy-Nexus-UK-Brazil-Calls-for-Collaborative-Research-ESRC-Economic-and-SocialResearch-Council.pdf (accessed on 11 December 2019).

35. Economic Social Research Council (ESRC). Funding Call Centre for Evaluating Complexity across the Energy-Environment-Food Nexus. 2015. Available online: https://valuing-nature.net/news/ funding-opportunity-centre-evaluating-complexity-across-energy-environment-food-nexus (accessed on 11 December 2019).

36. Belmont Forum \& Joint Programming Initiative (JPI) Urban Europe. Sustainable Urbanisation Global Initiative (SUGI)/Food-Water-Energy Nexus. [WWW Document]. 2016. Available online: https://jpiurbaneurope.eu/calls/sugi/ (accessed on 11 December 2019).

37. The World Bank Group. The World by Region. Available online: http://datatopics.worldbank.org/sdgatlas/ the-world-by-region.html (accessed on 27 October 2018). 
38. Gao, W.; Chen, Y.; Liu, Y.; Guo, H. Scientometric analysis of phosphorus research in eutrophic lakes. Scientometrics 2015, 102, 1951-1964. [CrossRef]

39. Wang, Q.; Yang, Z.; Yang, Y.; Long, C.; Li, H. A bibliometric analysis of research on the risk of engineering nanomaterials during 1999-2012. Sci. Total Environ. 2014, 473, 483-489. [CrossRef] [PubMed]

40. Muller, M. The 'nexus' as a step back towards a more coherent water resource management paradigm. Water Altern. 2015, 8, 675-694.

41. Radhakrishnan, S.; Erbis, S.; Isaacs, J.A.; Kamarthi, S. Novel keyword co-occurrence network-based methods to foster systematic reviews of scientific literature. PLOS ONE 2017, 12, e0172778. [CrossRef]

42. Berardy, A.; Chester, M.V. Climate change vulnerability in the food, energy, and water nexus: Concerns for agricultural production in Arizona and its urban export supply. Environ. Res. Lett. 2017, 12, 035004. [CrossRef]

43. Chang, Y.; Li, G.; Yao, Y.; Zhang, L.; Yu, C. Quantifying the water-energy-food nexus: Current status and trends. Energies 2016, 9, 65. [CrossRef]

44. De Laurentiis, V.; Hunt, D.V.L.; Rogers, C.D. Overcoming food security challenges within an energy/water/food nexus (EWFN) approach. Sustainability 2016, 8, 95. [CrossRef]

45. Habana, S.; Davidsen, C.; Bauer-Gottwein, P. Multi-objective optimization for analysis of changing trade-offs in the Nepalese water-energy-food nexus with hydropower development. Water 2017, 9, 162. [CrossRef]

46. Eftelioglu, E.; Jiang, Z.; Ali, R.; Shekhar, S. Spatial computing perspective on food energy and water nexus. J. Environ. Stud. Sci. 2016, 6, 62-76. [CrossRef]

47. El Gafy, I.; Grigg, N.; Reagan, W. Dynamic Behaviour of the Water-Food-Energy Nexus: Focus on Crop Production and Consumption. Irrig. Drain. 2017, 66, 19-33. [CrossRef]

48. Gençer, E.; Agrawal, R. Toward supplying food, energy, and water demand: Integrated solar desalination process synthesis with power and hydrogen coproduction. Resour. Conserv. Recycl. 2018, 133, 331-342. [CrossRef]

49. Hake, J.F.; Schlör, H.; Schürmann, K.; Venghaus, S. Ethics, sustainability and the water, energy, food nexus approach-A new integrated assessment of urban systems. Energy Procedia 2016, 88, 236-242. [CrossRef]

50. Heckl, I.; Cabezas, H.; Friedler, F. Designing sustainable supply chains in the energy-water-food nexus by the P-graph methodology. Chem. Eng. Trans. 2015, 45, 1351-1356.

51. Hussien, W.A.; Memon, F.A.; Savic, D.A. An integrated model to evaluate water-energy-food nexus at a household scale. Environ. Model. Softw. 2017, 93, 366-380. [CrossRef]

52. Ahuja, S. (Ed.) Food, Energy, and Water: The Chemistry Connection; Elsevier: Amsterdam, The Netherlands, 2015; pp. 1-461.

53. Garcia, D.; You, F. Systems engineering opportunities for agricultural and organic waste management in the food-water-energy nexus. Curr. Opin. Chem. Eng. 2014, 18, 23-31. [CrossRef]

54. Giampietro, M.; Aspinall, R.J.; Ramos-Martin, J.; Bukkens, S.G.F. (Eds.) Resource Accounting for Sustainability Assessment: The Nexus between Energy, Food, Water and Land Use; Routledge: London, UK; New York, NY, USA, 2014; pp. 1-248.

55. Stoy, P.C.; Ahmed, S.; Jarchow, M.; Rashford, B.; Swanson, D.; Albeke, S.; Bromley, G.; Brookshire, E.N.J.; Dixon, M.D.; Haggerty, J.; et al. Opportunities and Trade-offs among BECCS and the Food, Water, Energy, Biodiversity, and Social Systems Nexus at Regional Scales. Bioscience 2018, 68, 100-111. [CrossRef]

56. Badran, A.; Murad, S.; Baydoun, E.; Daghir, N. Water, Energy and Food Sustainability in the Middle East; Springer: Cham, Switzerland, 2017; pp. 1-440.

57. Jarvie, H.P.; Sharpley, A.N.; Flaten, D.; Kleinman, P.J.A.; Jenkins, A.; Simmons, T. The pivotal role of phosphorus in a resilient water-energy-food security nexus. J. Environ. Qual. 2015, 44, 1049-1062. [CrossRef]

58. Jeswani, H.K.; Burkinshaw, R.; Azapagic, A. Environmental sustainability issues in the food-energy-water nexus: Breakfast cereals and snacks. Sustain. Prod. Consum. 2015, 2, 17-28. [CrossRef]

59. Bellezoni, R.A.; Sharma, D.; Villela, A.A.; Pereira, A.O., Jr. Water-energy-food nexus of sugarcane ethanol production in the state of Goiás, Brazil: An analysis with regional input-output matrix. Biomass Bioenergy 2018, 115, 108-119. [CrossRef]

60. Bleischwitz, R.; Hoff, H.; Spataru, C.; van Der Voet, E.; VanDeveer, S.D. (Eds.) Routledge Handbook of the Resource Nexus; Routledge: London, UK, 2017; pp. 1-517. 
61. Gallagher, L.; Dalton, J.; Bréthaut, C.; Allan, T.; Bellfield, H.; Crilly, D.; Cross, K.; Gyawali, D.; Klein, D.; Laine, S.; et al. The critical role of risk in setting directions for water, food and energy policy and research. Curr. Opin. Environ. Sustain. 2016, 23, 12-16. [CrossRef]

62. Bell, A.; Matthews, N.; Zhang, W. Opportunities for improved promotion of ecosystem services in agriculture under the Water-Energy-Food Nexus. J. Environ. Stud. Sci. 2016, 6, 183-191. [CrossRef]

63. Finley, J.W.; Seiber, J.N. The nexus of food, energy, and water. J. Agric. Food Chem. 2014, 62, 6255-6262. [CrossRef] [PubMed]

64. Karabulut, A.; Egoh, B.N.; Lanzanova, D.; Grizzetti, B.; Bidoglio, G.; Pagliero, L.; Bouraoui, F.; Aloe, A.; Reynaud, A.; Maes, J.; et al. Mapping water provisioning services to support the ecosystem-water-food-energy nexus in the Danube river basin. Ecosyst. Serv. 2016, 17, 278-292. [CrossRef]

65. Leese, M.; Meisch, S. Securitising sustainability? Questioning the 'water, energy and food-security nexus'. Water Altern. 2015, 8, 695-709.

66. Rasul, G. Food, water, and energy security in South Asia: A nexus perspective from the Hindu Kush Himalayan region. Environ. Sci. Policy 2014, 39, 35-48. [CrossRef]

67. Cottee, J.; López-Avilés, A.; Behzadian, K.; Bradley, D.; Butler, D.; Downing, C.; Farmani, R.; Ingram, J.; Leach, M.; Pike, A.; et al. The local nexus network: Exploring the future of localised food systems and associated energy and water supply. Smart Innov. Syst. Technol. 2016, 52, 613-624.

68. Howarth, C.; Monasterolo, I. Understanding barriers to decision making in the UK energy-food-water nexus: The added value of interdisciplinary approaches. Environ. Sci. Policy 2016, 61, 53-60. [CrossRef]

69. Kurian, M. The Water-Energy-Food Nexus: Trade-Offs, Thresholds and Transdisciplinary Approaches to Sustainable Development. Environ. Sci. Policy 2017, 68, 97-106. [CrossRef]

70. Portney, K.E.; Hannibal, B.; Goldsmith, C.; McGee, P.; Liu, X.; Vedlitz, A. Awareness of the Food-Energy-Water Nexus and Public Policy Support in the United States: Public Attitudes Among the American People. Environ. Behav. 2018, 50, 375-400. [CrossRef]

71. Artioli, F.; Acuto, M.; McArthur, J. The water-energy-food nexus: An integration agenda and implications for urban governance. Polit. Geogr. 2017, 61, 215-223. [CrossRef]

72. Weitz, N.; Strambo, C.; Kemp-Benedict, E.; Nilsson, M. Closing the governance gaps in the water-energy-food nexus: Insights from integrative governance. Glob. Environ. Chang. 2017, 45, 165-173. [CrossRef]

73. Kibler, K.M.; Reinhart, D.; Hawkins, C.; Motlagh, A.M.; Wright, J. Food waste and the food-energy-water nexus: A review of food waste management alternatives. Waste Manag. 2018, 74, 52-62. [CrossRef] [PubMed]

74. Moioli, E.; Manenti, F.; Rulli, M.C. Assessment of global sustainability of bioenergy production in a water-food-energy perspective. Chem. Eng. Trans. 2016, 50, 343-348.

75. Holt, N.; Shukla, S.; Hochmuth, G.; Muñoz-Carpena, R.; Ozores-Hampton, M. Transforming the food-water-energy-land-economic nexus of plasticulture production through compact bed geometries. Adv. Water Resour. 2017, 110, 515-527. [CrossRef]

76. Hussien, W.A.; Memon, F.A.; Savic, D.A. A risk-based assessment of the household water-energy-food nexus under the impact of seasonal variability. J. Clean. Prod. 2018, 171, 1275-1289. [CrossRef]

77. Mortensen, J.G.; González-Pinzón, R.; Dahm, C.N.; Wang, J.; Zeglin, L.H.; Van Horn, D.J. Advancing the Food-Energy-Water Nexus: Closing Nutrient Loops in Arid River Corridors. Environ. Sci. Technol. 2016, 50, 8485-8496. [CrossRef]

78. Villarroel Walker, R.; Beck, M.B.; Hall, J.W.; Dawson, R.J.; Heidrich, O. The energy-water-food nexus: Strategic analysis of technologies for transforming the urban metabolism. J. Environ. Manag. 2014, 141, 104-115. [CrossRef]

79. Daher, B.T.; Mohtar, R.H. Water-energy-food (WEF) Nexus Tool 2.0: Guiding integrative resource planning and decision-making. Water Int. 2015, 40, 748-771. [CrossRef]

80. Vanham, D. Does the water footprint concept provide relevant information to address the water-food-energy-ecosystem nexus? Ecosyst. Serv. 2016, 17, 298-307. [CrossRef]

81. Lawford, R.; Bogardi, J.; Marx, S.; Jain, S.; Wostl, C.P.; Knüppe, K.; Ringler, C.; Lansigan, F.; Meza, F. Basin perspectives on the Water-Energy-Food Security Nexus. Curr. Opin. Environ. Sustain. 2013, 5, 607-616. [CrossRef]

82. Smajgl, A.; Ward, J. The Water-Food-Energy Nexus in the Mekong Region; Springer: New York, NY, USA, 2013. [CrossRef] 
83. Allan, T.; Keulertz, M.; Woertz, E. The water-food-energy nexus: An introduction to nexus concepts and some conceptual and operational problems. Int. J. Water Resour. Dev. 2015, 31, 301-311. [CrossRef]

84. Foran, T. Node and regime: Interdisciplinary analysis of water-energy-food nexus in the Mekong region. Water Altern. 2015, 8, 655-674.

85. Conway, D.; Van Garderen, E.A.; Deryng, D.; Dorling, S.; Krueger, T.; Landman, W.; Lankford, B.; Lebek, K.; Osborn, T.; Ringler, C.; et al. Climate and southern Africa's water-energy-food nexus. Nat. Clim. Chang. 2015, 5, 837-846. [CrossRef]

86. Ozturk, I. Sustainability in the food-energy-water nexus: Evidence from BRICS (Brazil, the Russian Federation, India, China, and South Africa) countries. Energy 2015, 93, 999-1010. [CrossRef]

87. McGrane, S.J.; Acuto, M.; Artioli, F.; Chen, P.Y.; Comber, R.; Cottee, J.; Farr-Wharton, G.; Green, N.; Helfgott, A.; Larcom, S.; et al. Scaling the nexus: Towards integrated frameworks for analysing water, energy and food. Geogr. J. 2018, 185, 419-431. [CrossRef]

88. Abbott, M.; Bazilian, M.; Egel, D.; Willis, H.H. Examining the food-energy-water and conflict nexus. Curr. Opin. Chem. Eng. 2017, 18, 55-60. [CrossRef]

89. White, D.; Wutich, A.; Larson, K.L.; Gober, P.; Lant, T.; Senneville, C. Credibility, salience, and legitimacy of boundary objects: Water managers' assessment of a simulation model in an immersive decision theater. Sci. Public Policy 2010, 37, 219-232. [CrossRef]

90. White, D.D. Framing water sustainability in an environmental decision support system. Soc. Nat. Resour. 2013, 26, 1365-1373. [CrossRef]

91. White, D.D.; Wutich, A.Y.; Larson, K.L.; Lant, T. Water management decision makers' evaluations of uncertainty in a decision support system: The case of WaterSim in the Decision Theater. J. Environ. Plan. Manag. 2015, 58, 616-630. [CrossRef]

92. May, P.J.; Sapotichne, J.; Workman, S. Policy coherence and policy domains. Policy Stud. J. 2006, 34, $381-403$. [CrossRef]

(C) 2020 by the authors. Licensee MDPI, Basel, Switzerland. This article is an open access article distributed under the terms and conditions of the Creative Commons Attribution (CC BY) license (http://creativecommons.org/licenses/by/4.0/). 